Abstracta Iranica

Revue bibliographique pour le domaine irano-aryen

Volume 37-38-39 | 2018

Comptes rendus des publications de 2014-2016

\title{
Agnès Lenepveu-Hotz. L'évolution du système verbal persan (Xe-XVIe siècles)
}

\section{Thomas Jügel}

\section{Q OpenEdition \\ 1 Journals}

\section{Electronic version}

URL: http://journals.openedition.org/abstractairanica/43061

DOI: 10.4000/abstractairanica.43061

ISBN: 1961-960X

ISSN: 1961-960X

Publisher:

CNRS (UMR 7528 Mondes iraniens et indiens), Éditions de l'IFRI

Electronic reference

Thomas Jügel, «Agnès Lenepveu-Hotz. L'évolution du système verbal persan (Xe-XVIe siècles) », Abstracta Iranica [Online], Volume 37-38-39 | 2018, document 14, Online since 30 December 2018, connection on 26 September 2020. URL : http://journals.openedition.org/abstractairanica/43061 ; DOI : https://doi.org/10.4000/abstractairanica.43061

This text was automatically generated on 26 September 2020

Tous droits réservés 


\title{
Agnès Lenepveu-Hotz. L'évolution du système verbal persan (Xe-XVIe siècles)
}

\author{
Thomas Jügel
}

\section{REFERENCES}

Agnès Lenepveu-Hotz. L'évolution du système verbal persan (Xe-XVIe siècles). Leuven/Paris: Peeters, 2014, 380 p., (Collection linguistique de la Société de linguistique de Paris, 100). ISBN (Belgium): 978-90-429-3225-8; ISBN (France): 978-2-7584-0239-8.

1 Lenepveu-Hotz's (henceforth LH) detailed corpus study is the revised version of her PhD thesis from 2012, for which she won the European Award of Iranian Studies of the Societas Iranologica Europaea in 2015. It is the first comprehensive study of the verbal system in early New Persian texts since Gilbert Lazard's seminal work La langue des plus anciens monuments de la prose persane of 1963 (Paris: Klincksieck). LH's study mostly includes (parts of) new texts which cover the centuries under study and several dialectal areas (nicely visualised on a map, p. 42 figure 0.1). Owing to its clear structure, this work should also be easy to handle for non-native speakers of French. 463 fully glossed examples, 54 tables, five diagrams and one map illustrate LH's findings, which she discusses with high philological expertise.

2 The study would have benefited from an appendix listing the attestations of her findings (cf. Lazard 1963). This would facilitate future research on specific topics, and one can only hope that a supplementary volume providing this information will appear (perhaps online?) in the future.

In 16 chapters, LH investigates several topics of the verbal system from rather formal questions (like the forms of verbal endings) to the functional development of a specific verb form (like the perfect). The development of form and function runs as a common thread through the whole book, and LH attempts to identify variation as either chronological or dialectal. 
Chapter I (pp. 43-60) is devoted to the form of verbal endings, notably their vocalisation, placement and omission. Chapter II (pp. 61-75) discusses the development of synthetic and analytic passives, the latter with the auxiliaries amadan 'to come', gaštan 'to turn', and šudan 'to go'. This issue is similar to the evolution of an analytic future with the auxiliary xwāstan 'to want' (chapter VIII, pp. 183-197), which is attested with long and short infinitives. The short and extended variants of infinite forms are investigated in chapters III and IV (III: infinitives like kardan vs. kard pp. 77-90; IV: past participles like karda vs. kard pp. 91-101). Long and short infinitives are also used with modal verbs, cf. chapter XII (pp. 269-301), and the semantics of modal expressions is discussed in the following chapter XIII (pp. 303-312). The synthetic modal expressions are presented in chapter IX (indicative, subjunctive, optative, and imperative; pp. 199-207) with chapter XI focusing on the 3sg. subjunctive of the verb 'to be/become' buvad vs. bāšad (pp. 251-268). The evolution of affixes is discussed in chapters V (grammaticalisation of hamē, pp. 103-137), VI (semantics of $-\bar{e}, \mathrm{pp} .139-162$ ), and X (semantics of bi-, pp. 209-249). Chapter VII (pp. 163-182) is devoted to the form and function of the perfect and its evidential marking (called "mediatif" by LH).

5 The study is summarised and evaluated in chapters XIV-XVI: the temporal and aspectual oppositions (pp. 313-318), synthetic and analytic forms (pp. 319-328), and the stages of development of the verbal system (pp. 329-334). The book is concluded by indices of linguistic terms and languages (pp. 335-339) and verbal forms quoted in this book (pp. 341-353) and the bibliography (pp. 355-380).

6 LH aims at presenting an in-depth analysis of the historical development of the verbal system. Owing to the lack of information concerning the Middle Persian and subsequent New Persian stages (a few studies have been published in the meantime), LH exercises caution when evaluating her findings. In general, she can identify three scenarios for grammatical change: homophony (one form for more than one function), competition (more than one form for one function) and loss and subsequent replacement (a form disappears and the gap is filled by a new one). Her findings illustrate that the series of developments characterising the transition from Middle Persian to New Persian could not all be ascribed to a specific time in history but occurred separately over several centuries. This shows that New Persian did not follow Middle Persian as a new language replacing an older one (as claimed at times).

This work will be an indispensable reference for all studies on the historical stages of Persian. It forms a treasure of observations for typological and historical linguistics, substantiating theoretical concepts with qualitative analyses.

\section{AUTHORS}

THOMAS JÜGEL

Mondes iranien et indien 